\title{
Awareness of Copyright Laws among Select Nigerian University Students
}

\author{
Allen Nnanwuba Adum \\ Department of Mass Communication, \\ Nnamdi Azikiwe University, Awka, \\ Anambra State, Nigeria \\ Ogochukwu Ekwenchi \\ Department of Mass Communication, \\ Nnamdi Azikiwe University, Awka, \\ Anambra State, Nigeria \\ Emeka Odogwu \\ Department of Mass Communication, \\ Nnamdi Azikiwe University, Awka, \\ Anambra State, Nigeria \\ Kobimdi Umeh \\ Department of Mass Communication, \\ Nnamdi Azikiwe University, Awka, \\ Anambra State, Nigeria
}

\begin{abstract}
Copyright laws have been in existence in Nigeria since independence and gone through several reviews. Although the policy of "permitted use" in the copyright law allows the reproduction of publications for educational and private use, studies have shown that students of tertiary institutions infringe on the copyright law. This study investigated the extent to which university students, precisely, Nnamdi Azikiwe University undergraduate students are aware of copyright laws. We used the survey research method to study a sample size of 400 drawn from a student population of over thirty thousand. Questionnaire was administered as instrument for data collection. Results revealed that most of these students were aware of copyright laws and the consequences of violating the law, yet compliance with the law was low among them. It was also revealed that even though photocopying is the number one activity which violates copyright laws on campuses of tertiary institutions, not much is being done to enforce the law.
\end{abstract}

Keywords: Copyright laws, photocopying, publications, promotion of knowledge

DOI: $10.7176 / J L P G / 86-19$

Publication date:June $30^{\text {th }} 2019$

\section{Introduction}

Oftentimes, Nigerian lecturers and course designers use copyrighted materials to teach and also to design courses. As a result of this, the Students also often consult copyrighted materials to meet their educational course work requirements. Consequently, in such an environment, lack of copyright awareness may result in uncontrollable copyright infringement.

For instance, one can easily notice that the absence of proper copyright/intellectual property right policy at Nigerian universities among has contributed to the mushrooming of commercial photocopy centres and other copyright infringement activities among Students. This was confirmed in a cursory survey, where it came to light 
that these commercial photocopy centres are not effectively regulated. In spite of this unfortunate situation, there are no copyright awareness notices displayed at these places where photocopying activities are undertaken thus, notices that would inform the Students and other users of the quantity of materials that may be legally photocopied for permitted use or fair use under section 19 of the Copyright Act, 2005 (Act 690). In universities in the developed countries, there are clear Copyright Policies to guide teaching, learning and the promotion of knowledge whilst not infringing on authors' rights.

One may even wonder what happens at a University where there is no copyright policy in this era where copyright infringement has become more evident with the emergence of advanced technology, as it is now possible to copy any material in volumes; and these works are likely protected by copyright. The situation at Nnamdi Azikiwe University reveals that many Students, who cannot afford the prices of materials and textbooks, now make photocopies of essential texts and materials for their academic work to the detriment of the copyright holders.

As a result of the lack of official copyright policy for universities, the University Faculty members and students are at 'liberty' to use copyrighted works with impunity, with no recourse to whom it may hurt. However, it can only be concluded that the harm caused by copyright infringement do not only affect authors, but also publishers and other stakeholders in the publishing industry.

\section{The Problem}

Literature, both recent and past has established that copyright laws are very important for better creativity on the part of the authors and protection of intellectual content. However, it is not certain if information users actually have a reasonable level of knowledge of these copyright laws as a means of protecting the intellectual creativity of respective authors. They might have reasonable level of knowledge of these but still infringe on the laws.

It is also believed that in Nigeria, the copyright law is not as effective as expected since no proper mechanism is put in place to curb infringement. Various forms of infringement are still practiced on a reasonable scale in higher institutions of learning despite the copyright laws.

\section{Purpose}

The concern of this study therefore is to determine the level of awareness and the different perceptions of undergraduate students in Nnamdi Azikiwe University Awka, Anambra State, Nigeria, on the issue of copyright laws. We therefore sought answers to the following questions:

1. How aware are undergraduates in Nnamdi Azikiwe University of copyright infringement and the provisions of the copyright law?

2. What are the major ways in which internet has led to this infringement?

3. How are access and availability of online learning resources responsible for the infringement of copyright laws by undergraduates?

4. What are the students' views on the issue of copyright infringement?

\section{Literature}

Empirical literature abounds on the subject of copyright awareness and infringement among university students.

Okiy (2005) investigated the photocopying practices in tertiary institutions in Nigeria as they related to existing copyright laws regulating photocopying practices so that the infringement of copyright laws will be minimized. Results revealed that the major reasons for photocopying was the cheapness of photocopies compared with the

cost of purchasing books and journals as well as the scarcity of books. More than 50 per cent of the respondents photocopied whole books and journals, even when over 65 per cent of them were aware of the copyright law.

Copyright laws are legal instruments that protect intellectual creativity of scholars. Aboyade, Aboyade and Ajala (2015) conducted descriptive survey find out the perception of Nigerian students and teachers on copyright law 
in relation to the abuse of published works. Stratified and simple random sampling techniques were used to select 800 students and teachers in federal universities in South-West Nigeria. Findings show that majority of the respondents feigned ignorance of the knowledge of copyright laws. They also said they had never made photocopie of published works.

Charbonneau and Priehs (2014) conducted a national survey of among 226 academic librarians and library staff in the United States about their awareness of various copyright policies, partnerships with campus groups to address copyright issues, and training needs. Results show that a majority of the survey respondents reported that they had answered copyright-related questions in the workplace, yet only $49 \%(\mathrm{n}=98)$ of the respondents perceived they were prepared to provide copyright information to library users. Awareness of various copyright policies among librarians and staff members varied, while they expressed the desire for more copyright-related training.

Igudia (2016) assessed copyright infringement of electronic information contents among undergraduate students of University of Ibadan. The objectives were to assess the level of infringement of electronic information contents; find out the level of awareness of copyright infringement; investigate the factors responsible for copy right infringement; and access the impact of social media on copyright infringement. Findings show that the level of copyright infringement of electronic contents was very high (above 80\%). Lack of awareness, ignorance, academic work pressure, dearth of study materials, influence of social network and inability to acquire necessary reading materials were the factors that promoted copyright infringement. The study recommended that copyright courses should be designed and offered by all undergraduate students to create enlightenment. University authority, through the various faculty and departmental libraries, should subscribe to relevant online books and journals which should be made available to all students.

Tella and Oyeyemi (2017) examined undergraduate students' knowledge of copyright infringement at the University of Ilorin, Nigeria. Three hundred and seventy-two (372) undergraduate students, randomly selected from twelve universities, were surveyed. Findings show that majority of the respondents were aware of copyright infringement and had strong perception that copyright infringement was a form of intellectual dishonesty. In addition, the results indicated that downloading content from the internet without permission from the owner was the major way through which undergraduates mostly infringed on copyright. The findings further showed that high cost of textbooks was a contributing factor that leads students to infringe on copyright law, followed by scarcity of materials, fear of scoring poor marks, lack of awareness and overarching curricula while the desire to defy authority had the least influence. They study suggested increasing awareness of copyright law and possible punishment for violating copyright as the most fundamental way of reducing copyright infringement.

Librarians are widely regarded as the custodians of most intellectual property. Fabunmi (2007) opines that librarians have the responsibility to protect the copyright of authors. In this regard they need to pay close attention to the balance between promoting the users' right as well as creators' right. They have the duty to discourage library users from infringing on copyright laws.

Eze and Ugwuanyi (2016) opine proper awareness of copyright implications on the part of copyright owners, abusers, and the public is at the root of intellectual property abuses. They further hold that proper administration of copyright law is the surest way of enhancing intellectual and scholarly growth and development and the public must rise to the challenges imposed by abuses in order to let copyright prevail.

Okere, Adam and Sanusi (2016) hold that the Nigerian educational system places little or no premium on intellectual property education; consequently, the efforts of both students and teachers at scholarship are seriously plagued with various sheds of copyright violation. They note that one predominant, yet often, casually regarded issue was plagiarism. They conducted four sessions of focus group discussion with eight final year students of Mass Communication at Babcock University, Ilishan-Remo, Ogun State and Redeemers University, Ede, Osun State. Each institution had four participants, two female and two male. Their input was collated and discussed qualitatively. A major finding was that there was a gap in intellectual property education especially regarding students' awareness of plagiarism as copyright violation. They therefore advocated the introduction and effective implementation of intellectual property education in the curriculum of Nigerian tertiary institutions.

According to Glover, Korletey and Kpodo (2016), plagiarism and intellectual dishonesty have become endemic among the academia with its resultant dwindling of academic integrity and honor. Flexible technologies of cut, copy and paste tools which are easily accessible to students, lecturers and the research community, who are tempted to turn to the internet for prepared literature and scholarly solutions, instead of originating independent works, facilitates this academic 'fraud'. The study focused on the students and lecturers of Kwame Nkrumah University of Science and Technology, Kumasi, Ghana (KNUST). Findings reveal that despite the fact that 
KNUST has no documented Copyright Policy Document (CPD), it regards plagiarism as an act of academic dishonesty. Lecturers ensure that students cite references to all the materials they use in their works and finally the university administration has included the subject of plagiarism in the Students' Guide book which is made available to all students on admission. Also, findings reveal that, though KNUST has put in place measure to fight and prevent plagiarism among the students, there is low level of awareness about plagiarism amongst KNUST students.

Olubiyi, I.A. (2014) holds that copyright owners have the exclusive right to control the reproduction of their works. The technology of private recording and copying technology is damaging to the right of owners and the entire copyright industry. The paper aligns with Nigerian Copyright Levy Order 2012 which imposes a levy for copyright infringement under the harm/compensation rationale and the statutory license rationale.

The findings in majority of the reviewed studies suggest that copyright laws are ineffective at the least to protect intellectual content.

\section{Method}

We designed our study as a survey. The undergraduate students of Nnamdi Azikiwe University Awka were purposively selected for the population of this study. Nnamdi Azikiwe University is one of the five federal universities created to ensure equitable access to education and satisfy regional interests. The student population of the school is about 30, 368 (according to the Students' Affairs Unit). A sample of 400 was drawn from the study population of 30,368 using Yamane's formula for calculating sample size: $n=N / 1+N(e)^{2}$. The multistage sampling procedure was used to select study units across the faculties, departments and academic levels.

The first stage involved the selection of faculties from Nnamdi Azikiwe University. The Faculty of Arts and Humanities, Social Sciences, Faculty of Engineering and Management Sciences were randomly selected.

The third stage saw the selection of departments. The department of philosophy and the department of English language and literature were randomly selected from the Faculty of Arts and Humanities. For the Faculty of Social Sciences, the Department of Psychology and Mass Communication were randomly selected. The Department of Metallurgical and Material Engineering and the Department of Chemical Engineering were randomly selected from the Faculty of Engineering. Also, for the Faculty of management, the department of Banking and Finance and Accountancy were randomly selected.

The fourth stage saw the selection of levels of study which was randomly done. For the department of philosophy, levels 200 and 300 were randomly selected. For the department of English and Literature, levels 100 and 400 were randomly selected. For the department of Psychology, levels 300 and 400 were randomly selected. For the department of Mass Communication, levels 300 and 200 were randomly selected. For the department of Metallurgical Engineering, levels 100 and 300 were randomly selected. For the department of Chemical Engineering, levels 400 and 100 were randomly selected. For the Department of Banking and Finance, levels 200 and 300 were randomly selected. For the Department of Accountancy, levels 100 and 200 were randomly selected.

The questionnaire was the research instrument used for the collection of the data. The questionnaire consisted of questions which were constructed in a way that the first stage sought the demography (personal data) of the respondents while the others are related to the subject matter of study. Both open and closed ended questions were used.

Data for this study was collected within a month and a half. We personally distributed and collected copies of the questionnaire from the respondents; as a result, we had a $99 \%$ rate of return.

\section{Data Analysis}

Demographic representations show that among our respondents we have 288 males (72\%) and 112 females $(28 \%) ; 64(16 \%)$ of respondents were of the age range $18-25 ; 288(72 \%)$ were of the age range $26-30$ years while $48(12 \%)$ were 31 and above.

Research question 1 asked: How aware are undergraduates in Nnamdi Azikiwe University of copyright infringement and the provisions of the copyright law? 
Tables 3 and 4, provide the answer. Table 3 shows that all the respondents are aware of copyright infringement, as $400(100 \%)$ of them admitted it. Table 4 shows that among the 400 respondents, $160(40 \%)$ do not have knowledge of copyright laws, while $240(60 \%)$ admitted having such knowledge.

The answers from this research question show that there is a high level of knowledge of copyright infringement by Nnamdi Azikiwe undergraduates.

Table 3: Respondents that have Knowledge of Copyright infringement

\begin{tabular}{|l|l|l|}
\hline Variables & Frequency & Percent \\
\hline Yes & 400 & $100 \%$ \\
\hline Total & 400 & $100 \%$ \\
\hline
\end{tabular}

Table 4: Respondents that have knowledge of copyright laws

\begin{tabular}{|l|l|l|}
\hline Variables & Frequency & Percent \\
\hline No & 160 & $40 \%$ \\
\hline Yes & 240 & $60 \%$ \\
\hline Total & 400 & $100 \%$ \\
\hline
\end{tabular}

Research question 2 asked: What are the major ways in which internet has led to this infringement?

Table 5 and 6 present the answers suggesting that $400(100 \%)$ of the respondents agree that the internet is more relevant to researchers than libraries; all of them (100\%) agree that the internet provides researchers with better accessible means of getting research materials than libraries. $400(100 \%)$ of them are of the view that the internet has encouraged plagiarism in Nigerian Universities. These answers mean that the internet has and would continue to be a good research source that provides a better and easier means of accessing books/materials for research than the libraries but has indirectly increased the level of plagiarism.

Table 5: Respondents that utilize academic resource materials (textbooks, journals etc. both in soft and hard copies) for research purposes

\begin{tabular}{|l|l|l|}
\hline Variable & Frequency & Percent \\
\hline Yes & 400 & $100 \%$ \\
\hline No & 0 & 0 \\
\hline Total & 400 & $100 \%$ \\
\hline
\end{tabular}

Table 6: Respondents' rate of browsing the net for research purposes

\begin{tabular}{|l|l|l|}
\hline Variables & Frequency & Percent \\
\hline Always & 240 & $60 \%$ \\
\hline Few times & 144 & $36 \%$ \\
\hline Seldom & 16 & $4 \%$ \\
\hline Total & 400 & $100 \%$ \\
\hline
\end{tabular}

Research question 3: How are access and availability of online learning resources responsible for the infringement of copyright laws by undergraduates?

Tables 7, 8, and 9 show that $400(100 \%)$ of the respondents are of the view that the internet has encouraged plagiarism in Nigerian Universities, especially Nnamdi Azikiwe University. This means that the ready access of the internet, though offering some advantages, inadvertently provides the platform for plagiarism. 
Table 7: Respondents' thoughts on relevance of the internet

\begin{tabular}{|l|l|l|}
\hline Variables & Frequency & Percent \\
\hline Yes & 400 & $100 \%$ \\
\hline No & 0 & 0 \\
\hline Total & 400 & $100 \%$ \\
\hline
\end{tabular}

Table 8: Respondents' view on if the internet has encouraged copyright infringement like plagiarism

\begin{tabular}{|l|l|l|}
\hline Variables & Frequency & Percent \\
\hline Yes & 400 & $100 \%$ \\
\hline No & 0 & 0 \\
\hline Total & 400 & $100 \%$ \\
\hline
\end{tabular}

Table 9: Respondents that have plagiarized before

\begin{tabular}{|l|l|l|}
\hline Variables & Frequency & Percent \\
\hline Yes & 160 & $40 \%$ \\
\hline No & 0 & 0 \\
\hline Undecided & 240 & $60 \%$ \\
\hline Total & 400 & $100 \%$ \\
\hline
\end{tabular}

Research question 4 asked: What are the students' views on the issue of copyright infringement?

Table 10 shows that among the respondents, 11 of them admitted they know about cases of plagiarism among their colleagues; $203(51 \%)$ said that their colleagues don't plagiarize while $186(44.6 \%)$ did not know if their colleagues plagiarize.

Table 10: Respondents that know about cases of plagiarism among their fellow students

\begin{tabular}{|l|l|l|}
\hline Variables & Frequency & Percent \\
\hline Yes & 11 & $4.4 \%$ \\
\hline No & 203 & $51 \%$ \\
\hline Unaware & 186 & $44.6 \%$ \\
\hline Total & 400 & $100 \%$ \\
\hline
\end{tabular}

Table 11 shows that $173(43 \%)$ of the respondents are of the view that the level of copyright infringement among Unizik undergraduate students is high; 71 respondents are of the view that it is very high; 100 respondents said it is low; while $56(14 \%)$ opined that the level of copyright infringement among Unizik undergraduates was very low.

Table 11: Respondent's view on the level of copyright infringement among undergraduates

\begin{tabular}{|l|l|l|}
\hline Variables & Frequency & Percent \\
\hline High & 173 & $43 \%$ \\
\hline Very High & 71 & $18 \%$ \\
\hline Low & 100 & $25 \%$ \\
\hline Very Low & 56 & $14 \%$ \\
\hline Total & 400 & $100 \%$ \\
\hline
\end{tabular}




\section{Conclusion}

Copyright is the exclusive right of an author to restrict others from copying his work. Copyright awareness is essential in academic and scholarly environment where the people use others work to create their own works. The development in technology facilitates the easiest way of accessing information resources and reproducing them. It will lead to the great problem of copyright infringement or copyright violation.

The present study is an attempt made by the investigators to study the level of copyright awareness among students in Nnamdi Azikiwe University, Awka, Anambra State, Nigeria. The findings of the study reveal that majority of the students are aware about copyright law and its importance. The study also reveals that a majority of the students are less aware about plagiarism. The study also helped the investigators to reach the conclusion that copyright is relevant in digital environment. Copyright infringement or violation has negative effect on intellectual creativity.

\section{Recommendations}

Based on the findings of this study, the following were recommended:

1. There should be policy development on copyright infringement at Nnamdi Azikiwe University.

2. Workshop and seminars should be organized for sudents at their various faculties and departments to educate them on copyright laws in order to reduce copyright infringement.

3. Copyright notices to, educate students, should be placed at places where copyrighted materials are used such as The Library and Lecture Halls.

4. References in Students works should attract marks to motivate them to see the need for crediting sources of information they use in their write up.

\section{References}

Aboyade, W.A., Aboyade, M.A. \& Ajala, B.A. (2015). Copyright infringement and photocopying services among university students and teachers in Nigeria, International Journal of Arts \& Sciences, 08(01) p.463-472.

Charbonneau, D.H., \& Priehs, M. (2014). Copyright partnerships and training issues in academic libraries, Journal of Academic Leadership, Vol. 40, Issue 3-4 p.228-233

Eze, C.C., Ugwuanyi, R.N.C. \& Ugwu F. N. (2016). Copyright law and intellectual property abuses in Nigeria: Impact on creativity and academic output, Journal of Applied Information Science and Technology, 9(2) p133137.

Fabunmi, B. A. (2007). The roles of librarians in copyright protection in Nigeria, International Journal of African \& African American Studies Vol. vi, No.1, Jan 2007.

Glover, R.S.K., Korletey, J.T. \& Kpodo, C.S. (2016). Fighting plagiarism among students through copyright awareness and policy: A focus on Kwame Nkrumah University of Science and Technology, European Journal of Research in Social Sciences, Vol. 4 No.3.

Igudia, O.E., (2016). Awareness and indulgence in copyright infringement of internet information contents among distance learning undergraduates of University of Ibadan, Nigeria, Retrieved from: https://www.researchgate.net/publication/322387251 Awareness and indulgence in copyright Infringement o f_Internet_Information_Contents_among_Distance_Learning_Undergraduates_of_University of Ibadan_Nigeri $\underline{\mathrm{a}}$

Okere, S., Adam, M.E. \& SAnusi B.O. (2016). Awareness of plagiarism as copyright violation with implications for intellectual property education in tertiary learning, Journal of Research and Development, Vol. 3.No. 1.

Okiy, R. B. (2005). Photocopying and the awareness of copyright in tertiary institutions in Nigeria, Interlending \& Document Supply, Vol. 33 Issue: 1, p. 49-52.

Olubiyi, I.A. (2014). Imposition of copyright levy in Nigeria: Legal justifications and comparative analysis, Afe Babalola University Journal of Sustainable Development Law and Policy, Vol. 4 Issue 1

Tella, A., Oyeyemi, F. O. (2017) Undergraduate students' knowledge of copyright infringement. Brazilian Journal of Information Studies: Research Trends. 11:2 (2017) p.38-53. 